EXPERIMENTAL STUDY

\title{
Gender and gonadal influences on ghrelin mRNA levels in rat stomach
}

\author{
O Gualillo ${ }^{2}$, J E Caminos ${ }^{1}$, M Kojima ${ }^{3}$, K Kangawa ${ }^{3}$, E Arvat $^{4}$, E Ghigo ${ }^{4}$, F F Casanueva ${ }^{2}$ and C Diéguez ${ }^{1}$ \\ ${ }^{1}$ Department of Physiology and ${ }^{2}$ Department of Medicine, Molecular Endocrinology Section, School of Medicine, University of Santiago de Compostela, \\ Spain, ${ }^{3}$ Department of Biochemistry, National Cardiovascular Center Research Institute, Osaka, Japan and ${ }^{4}$ Department of Internal Medicine, University \\ of Turin, Italy \\ (Correspondence should be addressed to Carlos Diéguez, Department of Physiology, University of Santiago de Compostela, School of Medicine, C/ San \\ Francisco 1, 15705 Santiago de Compostela, Spain; Email: fscadigo@usc.es) \\ (O Gualillo is now at Santiago University Clinical Hospital, Trav Choupana sn, 15707 Santiago de Compostela, Spain) \\ (O Gualillo and J E Caminos have contributed equally to the realization of this study)
}

\begin{abstract}
Objective: The recently isolated endogenous GH secretagogue, named ghrelin, is a gastric peptide of 28 amino acids with an $n$-octanoylation in the serine 3 that confers the biological activity to this factor. Ghrelin has been shown to directly stimulate GH release in vivo and in vitro and to be involved in the regulation of gastric acid secretion and motility. In the present work we have studied gender and gonadal dependency of ghrelin mRNA expression in rat stomach.

Design and Methods: We analysed ghrelin mRNA expression in rat stomach by Northern blot analysis. We also examined the effect of gonadal steroid deprivation on ghrelin mRNA expression.

Results and Conclusions: The results obtained showed clearly that ghrelin gastric mRNA expression increased with age in young rats (up to 90 days old) but exhibited no significant sex difference at each age tested. Ghrelin mRNA levels were lowest at postnatal day 9, reaching a stable level of expression at day 40 in both female and male rats, although the increase in female rats appears much more gradual than that in males. Moreover, neither ovariectomy nor orchidectomy significantly modified ghrelin mRNA gastric levels in adult rats. In conclusion, these data indicate that ghrelin mRNA expression is associated with age and that a progressive increase is present from the perinatal period up to a stable level after puberty. Gonadal hormones did not alter ghrelin mRNA levels. Taken together, these data showed that ghrelin mRNA levels in young rats are age but not gender dependent, and are not influenced by gonadal steroids.
\end{abstract}

European Journal of Endocrinology 144 687-690

\section{Introduction}

Growth hormone secretagogues (GHSs) are artificial compounds which release GH in all species tested so far. Up to now, these molecules mimicked an unknown endogenous factor that activates the GHS receptor (GHS-R). The earlier cloning of GHS-R (1) suggested that an endogenous ligand for this receptor might exist. Indeed, after intensive research by different groups, the isolation of an endogenous ligand of the GHS-R, named ghrelin (2), was recently reported. The purified ligand was found to be a peptide of 28 amino acids, in which the serine 3 residue, was n-octanoylated. This peptide has been shown to exert a very potent and specific GHreleasing activity both in vivo and in vitro. Taking into account that it is secreted predominantly from the stomach and that ghrelin circulates in normal subjects at considerable plasma concentrations, it has been postulated that this molecule is secreted from the stomach, and circulates in the blood stream to stimulate $\mathrm{GH}$ secretion by the somatotrophs. Furthermore, ghrelin has been shown to regulate gastric acid secretion and motility in rats, indicating that this peptide may well be involved in the regulation of gastrointestinal function (3).

It has been observed that the levels of neuroendocrine peptides change with age. This change occurred in the stomach as well as in the small and large intestine (4). In some cases, changes are influenced by puberty while in others they are independent of gonadal function.

The aim of this paper was to evaluate the influence of age and gonadal function on ghrelin mRNA levels in rat stomach.

\section{Materials and methods}

\section{Animals and experimental procedures}

Experimental set 1 In order to ascertain possible agerelated changes in ghrelin RNA expression we have 
used male and female Sprague-Dawley rats of different ages: 9, 21, 40, 60 and 90-day-old rats. Rats were housed with a $12 \mathrm{~h}$ light:12 h darkness cycle with free access to food and water. Once they achieved the appropriate age, rats were euthanasized and the stomach was rapidly excised and snap-frozen on dry ice until use and/or immediately processed for RNA isolation.

Experimental set 2 To analyse the effect of gonadal hormones on ghrelin expression, male and female 60-day-old Sprague-Dawley rats were respectively orchidectomized and ovariectomized under ketamine anaesthesia. Sham intact operated rats were used as control. After the surgical procedure, rats were housed in standard conditions with free access to food and water. Rats were killed 5, 10 and 15 days after the gonadectomy. Stomach was excised and processed as previously described.

\section{Statistical analysis}

Data are expressed as mean \pm s.E.M. and analysed with a computerized package for statistical analysis. Statistically significant difference was determined by ANOVA followed by post hoc multiple comparison test. A $P$ value $<0.05$ was considered as significant.

\section{Northern blot analysis}

Total stomach RNAs were extracted by a guanidium isothiocyanate-phenol method and $20 \mu \mathrm{g}$ of total RNA were fractionated by agarose gel electrophoresis. The $28 \mathrm{~s}$ and $18 \mathrm{~s}$ RNA bands were visualized by ethidium bromide staining with a Gel Doc 1000 Documentation System.

RNA was transferred by capillary blotting onto a charged nylon membrane and fixed with u.v. light. The filter was hybridized to a ${ }^{32} \mathrm{P}$-labelled cDNA probe (501 bp) to rat ghrelin. Rat ghrelin cDNA was purified from plasmid expression vector with Sephaglas BandPrep Kit (Pharmacia Biotech, Uppsala, Sweden). The probe was prepared by random prime labelling the rat ghrelin cDNA subcloned in EcoRI double restriction site of a $\operatorname{pBS}-\mathrm{SK}(-)$ expression vector. Hybridization was performed overnight at $42{ }^{\circ} \mathrm{C}$ in pre-hybridization buffer containing the labelled probe $\left(1 \times 10^{6}\right.$ c.p.m./ml), six post-hybridization washes were performed before the filter was exposed to x-ray film. Multiple exposure times, followed by densitometric analysis, were performed to ensure that the relative signals obtained indicated actual changes in mRNA levels and not merely artefacts due to any non-linearity in film exposure. Relative mRNA levels obtained at different exposure times gave similar quantitative alterations. A rat 18 s ribosomal RNA oligonucleotide probe 5'-ACGGTATCTGATCGTCTTCGAACC-3' (GibcoBRL, Barcelona, Spain) was used to assess the amount and integrity of total RNA loaded in each gel. The oligonucleotide was end-labelled with ${ }^{32} \mathrm{P}$ by polynucleotide kinase (Promega, Madison, WI, USA) and hybridized with filters in a buffer containing $10 \times$ Denhardt's solution, $0.1 \%$ SDS, $2 \times$ SSC and $100 \mu \mathrm{g} / \mathrm{ml}$ salmon sperm DNA at $50{ }^{\circ} \mathrm{C}$ for $24 \mathrm{~h}$. The filters were then successively washed and processed as described above.

\section{Results}

Male and female rats have similar levels of expression of ghrelin mRNA at all time points studied (Fig. 1), apart from a very significative difference in rats of 9 days of both sexes in comparison with animals of any other age. To note, 21-day-old female rats showed a statistically significant difference in comparison to 40day-old female rats. Gastric ghrelin mRNA content seems to change significantly only in the first part of maturation, remaining thereafter stable after 40 days of life both in female and male rats. In order to establish the effect of sexual steroid environment, we have assessed the effect of gonadectomy on adult male and female rats. As shown in Fig. 2, ghrelin mRNA levels in stomach of gonadectomized rats were unchanged throughout 5, 10 and 15 days after gonadectomy.

\section{Discussion}

Gastrointestinal hormones are known to influence the development of the gastrointestinal tract. Changes in peptide hormone gene expression usually reflect an adaptation to age-related changes, or are secondary to structural and functional changes in the alimentary tract. Ghrelin is the recently discovered endogenous ligand for $\mathrm{GH}$ secretagogues receptors. This 28 amino acid acylated peptide, with a potent $\mathrm{GH}$ releasing activity, was identified in rat stomach and it is present in the entire gastrointestinal tract, from the stomach to the colon (5). Moreover, it is present also in other tissues such as placenta (6). In addition to its neuroendocrine role, direct and indirect evidence indicates that the ghrelin system may well play an important role in the homeostasis of systems other than $\mathrm{GH}$, such as gastric secretion and motility (3), food intake (7), cardiac function (8) and sleep control (9).

The aim of the present study was firstly to investigate the ontogenic expression of ghrelin mRNA in stomach of male and female rats. We have demonstrated that the mRNA levels of stomach-derived ghrelin exhibit no significant sex differences, whereas we have observed age-dependent changes throughout postnatal development particularly during the first 40 days of life. Although no sex differences appear to be established either at earlier stages of development as well as in puberty and adulthood, marked differences are clearly evident during the first neonatal period in comparison to the levels observed in the advanced maturation. 

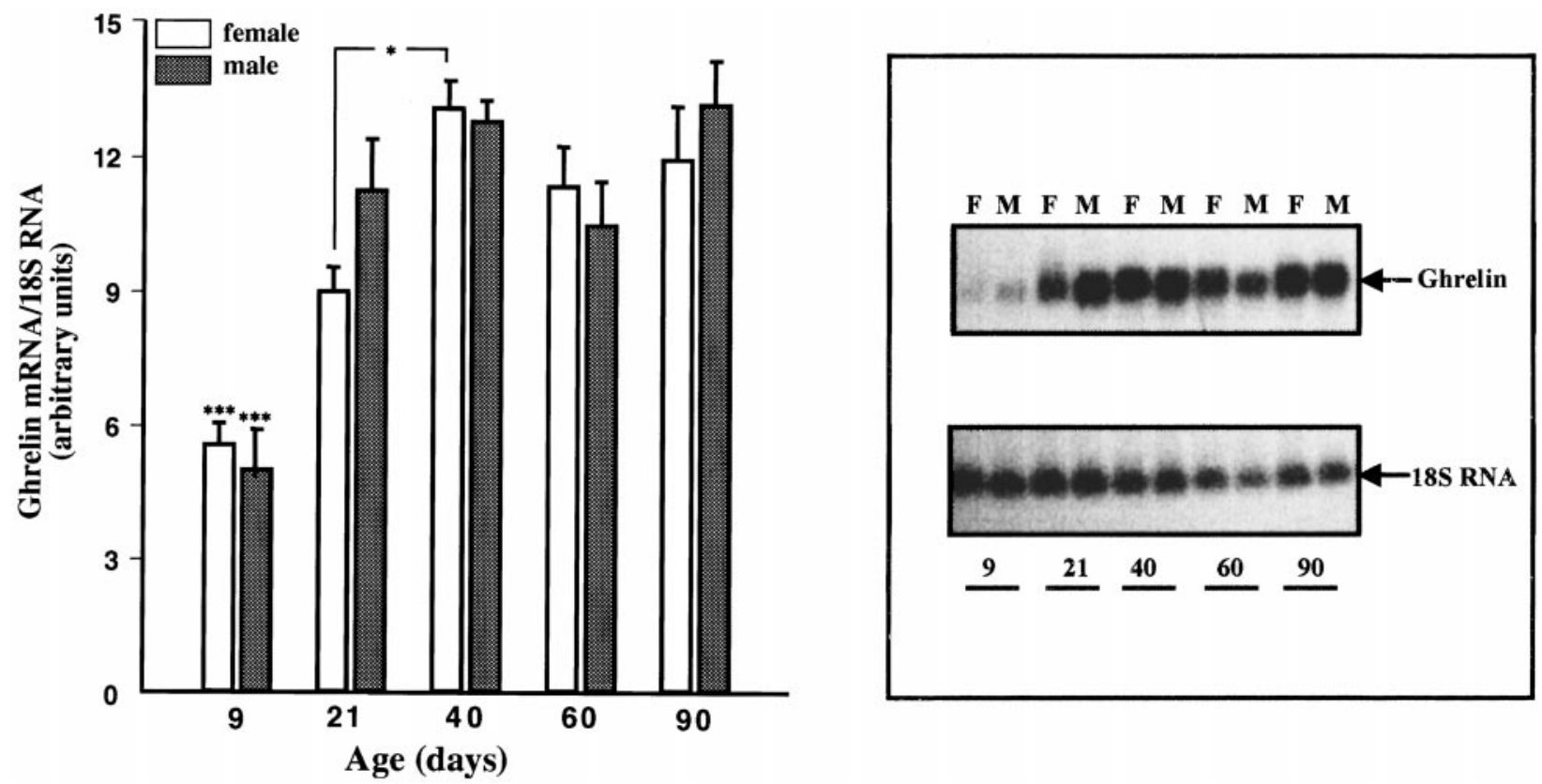

Figure 1 Ghrelin mRNA gastric expression in male and female rats of different ages. ${ }^{\star \star \star} P<0.001,{ }^{*} P<0.05$. The blot shown in the right panel is representative of at least six independent experiments.

Ghrelin mRNA in the stomach of 9-day-old male rats is low and reaches a level of expression at day 21 that remains stable along maturation. In female rats, a growing level of expression was observed until day 40, remaining stable after this time.

Next, we assessed whether gonadal steroids may also play an activational role on gastric ghrelin mRNA in the adult animal. Our data showed that ghrelin mRNA levels were unchanged in gonadectomized animals (5-

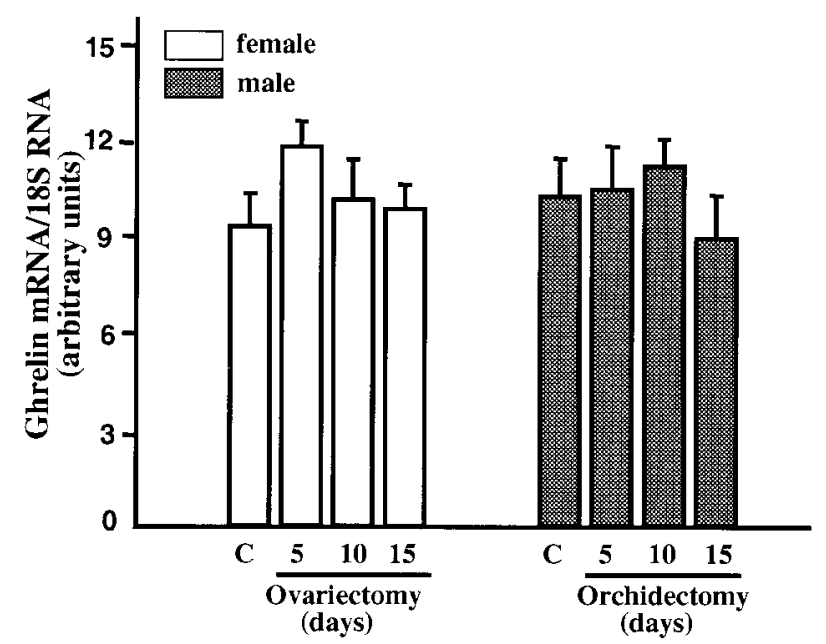

Figure 2 Effect of gonadectomy in adult male and female rats on ghrelin gastric mRNA expression. The effect was evaluated after different times (5, 10 and 15 days) in comparison with sham intact operated rats used as control.
10 and 15 days); this result seems to indicate that the pattern of ghrelin expression is not influenced by the result of the different gonadal hormonal environments present in adulthood. Whether the changes in ghrelin mRNA levels observed during the perinatal period are relevant to the development of the gastrointestinal tract or are a consequence of its maturation remain to be established. In any event, although stomach-derived ghrelin has been postulated to influence GH secretion (10-14), our data indicate that age- and genderrelated changes in $\mathrm{GH}$ levels are not associated with changes in stomach ghrelin mRNA levels. Our data showing that stomach ghrelin mRNA levels are not affected by gender indicate that this is not the source of the sexual dimorphism in the GH secretory pattern. In addition, GH levels in the rat are lowest at 18-22 days of age, increasing during the late prepubertal period and from the onset of puberty, resulting in the adult secretory pattern $(15,16)$. We failed to find a parallel increase in stomach ghrelin mRNA levels, arguing against both events being interrelated. Nevertheless, it is possible that maturational changes in neuropeptide release or in the somatotroph responsiveness to somatostatin, growth hormone-releasing hormone (GHRH) and ghrelin might contribute to the pattern of circulating GH levels. Although data regarding gender differences in hypothalamic and somatostatin content are conflicting (17), it has been shown that in vitro GH responses to GHRH are influenced by age and gonadal status (18). Although no data are currently available regarding the influence of gonadal function 
on in vitro GH responses to ghrelin, it should be noted that $\mathrm{GH}$ responses to hexarelin are greater at the late postpubertal period (19).

In summary, this study provide the first evidence for the following. (a) Gastric ghrelin mRNA expression increases from the perinatal period up to a stable level after puberty, the increase being more gradual in female than in male rats. No significant sex differences were observed at each age tested. (b) Ghrelin gastric mRNA expression appears not to be influenced by gonadal hormones in adulthood in both female and male rats.

\section{Acknowledgements}

Oreste Gualillo is a recipient of a Research Training Contract, Program of Improvement in Health Research from the Spanish Ministry of Health (Contract 00/ 3051). J Eduardo Caminos is a recipient of a predoctoral fellowship from the University of Santiago de Compostela. This work was supported by grants from Xunta de Galicia, DGCYT and Fondo de Investigación Sanitaria, Spanish Ministry of Health.

\section{References}

1 Howard AD, Feighner SD, Cully DF, Arena JP, Arvat E, Ghigo E et al. A receptor in pituitary and hypothalamus that functions in growth hormone release. Science 1996273 974-977.

2 Kojima M, Hosoda H, Date Y, Nakazato M, Matsuo H \& Kangawa K. Ghrelin is a growth hormone releasing acylated peptide from stomach. Nature $1999 \mathbf{4 0 2} 656-660$.

3 Masuda Y, Tanaka T, Inomata N, Ohnuma N, Tanaka S, Itoh Z et al. Ghrelin stimulates gastric acid secretion and motility in rats. Biochemical and Biophysical Research Communications 2000 276 905-908.

4 El Sahly M \& Sandstrom O. How age changes the content of neuroendocrine peptides in the murine gastrointestinal tract. Gerontology $1999 \mathbf{4 5}$ 17-22.

5 Date Y, Kojima M, Hosoda H, Sawaguchi A, Mondal MS, Suganume T et al. Ghrelin, a novel growth hormone acylated peptide, is synthesized in a distinct endocrine cell type in the gastrointestinal tract of rats and human. Endocrinology 200041 $4255-4261$.

6 Gualillo O, Caminos JE, Blanco M, Garcia Caballero T, Kojima M, Kangawa $\mathrm{K}$ et al. Ghrelin, a novel placental derived hormone. Endocrinology $2001 \mathbf{1 4 2} 788-794$.
7 Kangawa K, Kojima M \& Matsuo H. Isolation and implication of novel cardiovascular hormones. Proceedings of 82nd Annual Meeting of the Endocrine Society 2000. Abstract 172, p 38.

8 Wakabayashi I, Sugihara H \& Shibasaki T. Growth hormone secretagogue influences feeding behaviour in experimental animals. In Growth Hormone Secretagogues: Basic Findings and Clinical Implications. Eds E Ghigo, M Boghen, F F Casaneuva \& C Dieguez. Amsterdam: Elsevier Science, 1999.

9 Steiger A. Growth hormone secretagogues and sleep. In Growth Hormone Secretagogues: Basic Findings and Clinical Implications. Eds E Ghigo, M Boghen, F F Casaneuva \& C Dieguez. Amsterdam: Elsevier Science, 1999.

10 Arvat E, Di Vito L, Broglio F, Papotti M, Muccioli G, Dieguez C et al. Preliminary evidences that ghrelin, the natural GH secretagogue (GHS)-receptor ligand, strongly stimulates GH secretion in humans. Journal of Endocrinological Investigation 200023 493-495.

11 Date Y, Murakami N, Kojima M, Kuroiwa T, Matsukura S \& Kangawa K. Central effects of a novel acylated peptide, ghrelin, on growth hormone release in rats. Biochemical and Biophysical Research Communications 2000275 477-480.

12 Dieguez C \& Casanueva FF. Ghrelin: a step forward in the understanding of somatotroph cell function and growth regulation. European Journal of Endocrinology 2000142 413-417.

13 Seoane LM, Tovar S, Baldelli R, Arvat E, Ghigo E, Casanueva FF et al. Ghrelin elicits a marked stimulatory effect on GH secretion in freely moving rats. European Journal of Endocrinology 2000 143 R007-R009.

14 Jansson JO, Eden S \& Isaksson O. Sexual dimorphism in the control of growth hormone secretion. Endocrine Reviews 19856 $128-150$.

15 Eden S, Albetrsson-Wikland K \& Isaksson O. Plasma levels of growth hormone in female rats of different ages. Acta Endocrinologica (Copenhagen) $1978 \mathbf{8 8} 676-679$.

16 Jansson JO, Ekberg S, Olle G, Isaksson P \& Eden S. Influence of gonadal steroids on age and sex related secretory patterns of growth hormone in the rat. Endocrinology $19841141287-$ 1294.

17 Ho KY, Thorner MO, Krieg RJ, Lan SK, Johnson ML, Leong DA et al. Effect of gonadal steroids on somatotroph function in the rat: analysis by the reverse hemolytic plaque assay. Endocrinology $19881231405-1411$.

18 Aguilar E, Tene-Sampere M \& Pinilla L. Gonadal hormones and growth hormone secretion. In Regulation of Growth Hormone and Somatic Growth, pp 137-150. Ed L de la Cruz. Amsterdam: Elsevier, 1992.

19 Ghigo E, Arvat E, Muccioli G \& Camanni F. Growth hormonereleasing peptides. European Journal of Endocrinology 1997136 445-460.

Received 3 January 2001

Accepted 8 March 2001 